\title{
Edible mushrooms, a vulnerable ecosystem service from African miombo woodlands
}

\author{
Jérôme Degreef ${ }^{(1,2)}$, Bill Kasongo ${ }^{(3)}$, Elias Niyongabo ${ }^{(4)}$, André De Kesel ${ }^{(1)}$
}

(1) Meise Botanic Garden. Nieuwelaan, 38. BE-1860 Meise (Belgium). E-mail: jerome.degreef@botanicgardenmeise.be

(2) Fédération Wallonie-Bruxelles. Service Général de l'Enseignement supérieur et de la Recherche scientifique. Rue A. Lavallée, 1. BE-1080 Brussels (Belgium).

(3) Université de Lubumbashi. Faculté des Sciences agronomiques. Département de Gestion des Ressources Naturelles Renouvelables. BP 1825. Lubumbashi (DR Congo).

(4) Office Burundais de Protection de l'Environnement. Avenue de l'Imprimerie. BP 2757. Bujumbura (Burundi).

Received 14 August 2019, accepted 22 January 2020, available online 29 January 2020.

This article is distributed under the terms and conditions of the CC-BY License (http://creativecommons.org/licenses/by/4.0)

Description of the subject. Edible mushrooms are highly valuable non-wood forest products exploited for food and trade by local populations in the miombo area. Fungal diversity and natural production of edible mushrooms in African miombo woodlands are assessed and quantified for the first time.

Objectives. The study aims to characterize the mycodiversity and compare the natural production in different miombo types to help manage this vulnerable ecosystem service.

Method. A standardized data collection method was used in three study sites with different miombo types of Burundi and DR Congo. Sixty field surveys were conducted weekly in 22 permanent plots during fruiting periods.

Results. The study revealed a high variation in mycodiversity according to the miombo type. Based on fresh biomass production and compared to saprotrophic taxa, it is shown that ectomycorrhizal fungi represent the most productive edible fungal component in African miombo woodlands.

Conclusions. Since ectomycorrhizal host trees are systematically felled for fuelwood and charcoal production, their obligate symbiotic fungal partners are particularly vulnerable. It is suggested that for sustaining ecosystem services delivered by wild edible ectomycorrhizal fungi, forests dominated by host trees from the genera Julbernardia, Brachystegia, Isoberlinia, Uapaca and Marquesia, should be separed from clear-felling or frequent and excessive coppicing.

Keywords. Non wood forest products, fungi, forest management, tropical Africa.

Les champignons comestibles, un service écosystémique vulnérable des miombo africains

Description du sujet. Les champignons comestibles sont d'importants produits forestiers non ligneux exploités pour l'alimentation et le commerce par les populations de l'aire de distribution des miombo. La diversité et la production naturelle des champignons comestibles dans les miombo africains sont évaluées et quantifiées pour la première fois.

Objectifs. L'étude a pour objectifs de caractériser la diversité fongique et de comparer la production naturelle dans différents types de miombo dans le but d'aider à gérer ce service écosystémique vulnérable.

Méthode. Une méthode standardisée de collecte des données a été utilisée dans trois sites situés en RD Congo et au Burundi et abritant différents types de miombo. Soixante inventaires hebdomadaires ont été menés dans 22 placeaux permanents durant les périodes de fructification.

Résultats. L'étude a révélé une importante variation de la mycodiversité en fonction du type de miombo. Sur base de la production de biomasse fraiche et par comparaison avec les taxons saprotrophes, il apparait que les champignons ectomycorhiziens constituent la composante fongique la plus productive dans les miombo africains.

Conclusions. Comme les arbres hôtes ectomycorhizés sont systématiquement abattus pour la production de bois de feu et de charbon de bois, leurs partenaires symbiotiques obligatoires sont particulièrement vulnérables. Il est suggéré que, pour maintenir les services écosystémiques fournis par les champignons ectomycorhiziens comestibles, les forêts dominées par des arbres hôtes des genres Julbernardia, Brachystegia, Isoberlinia, Uapaca et Marquesia ne soient pas soumises à des coupes à blanc ou à une exploitation fréquente et excessive.

Mots-clés. Produits forestiers non ligneux, champignon, aménagement forestier, Afrique tropicale. 


\section{INTRODUCTION}

Miombo woodlands are important ecosystems that cover $\sim 10 \%$ of Africa. It is a thornless, deciduous woodland, typical of unimodal rainfall areas between latitudes $5^{\circ} \mathrm{S}$ and $17^{\circ} \mathrm{S}$, situated along the eastern and southern parts of the Congo Basin. The miombo region extends from East Africa (Burundi, Kenya, Tanzania, Uganda) to the Zambezian region (Angola, DR Congo, Malawi, Mozambique, Zambia, Zimbabwe). Miombo woodlands are characterized by trees not exceeding $15-20 \mathrm{~m}$ high with a mean density of $\sim 500$ individuals $\cdot \mathrm{ha}^{-1}$, responsible for the open aspect of the vegetation (Ribeiro et al., 2013). Although tree species composition largely depends on soil, slope, fire regime and disturbance, all miombo woodlands are dominated by Fabaceae-subfamily Caesalpinioideae (mainly Brachystegia, Julbernardia, Isoberlinia), Dipterocarpaceae (Marquesia) and Phyllanthaceae (various Uapaca species). Remarkably, most of these trees are associated in a symbiotic relationship with diverse ectomycorrhizal fungi (ECM).

Together with termite-grown fungi (Termitomyces spp.), most of the basidiomes produced by ECM in the miombo region are highly appreciated by local populations. With a regular consumption and an important local trade, these seasonal Non-wood forest products (NWFPs) substantially contribute to food security and the livelihood of millions of villagers.

Despite their socio-economic impact and importance to human health, the ecosystem services provided by edible mushrooms are jeopardized by the systematic destruction and decline of the ECM-host trees. The miombo region is indeed the most inhabited of tropical Africa and firewood or charcoal remain the most easily accessed energy sources for the populations in and around the big cities.

This study strives to accurately quantify the natural productivity of edible mushrooms using multi-year field data from different miombo woodlands obtained by a standardized methodology (De Kesel et al., 2002; Yorou et al., 2002; De Kesel et al., 2017). Similar research aiming to estimate (e.g. Boa, 2004; Egli et al., 2010; Bonet et al., 2014; Alday et al., 2017; Tomao et al., 2017; Collado et al., 2018) or model fungal production (e.g. Dahl et al., 2008; Bonet et al., 2010; Martínez-Peña et al., 2012; De Miguel et al., 2014; Hernández-Rodríguez et al., 2015; Tahvanainen et al., 2016; Herrero et al., 2019) were already conducted in Europe, in North America and in diverse subtropical regions, but the present study is the first for tropical Africa.

\section{MATERIALS AND METHODS}

\subsection{Study sites}

The Mikembo sanctuary ( $\sim 800$ ha) (southern DR

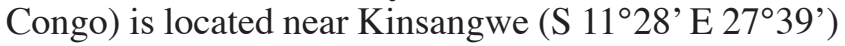
in the Zambezian regional center of endemism (White, 1986) (Figure 1). The mean annual temperature is $20{ }^{\circ} \mathrm{C}$, and the average annual precipitation is $1,200 \mathrm{~mm}$, occurring mainly from October to April. Our observations in Mikembo were conducted from December 2012 to April 2015 (60 weekly surveys) (Table 1).

The protected landscape of Gisagara $(\sim 6,000$ ha) (eastern Burundi) is located near Rusigabangazi (S $03^{\circ} 15^{\prime} \mathrm{E} 30^{\circ} 46^{\prime}$ ) in the Afromontane archipelagolike regional center of endemism (White, 1986) (Figure 1). The mean annual temperature is $20^{\circ} \mathrm{C}$, and the average annual precipitation is $1,030 \mathrm{~mm}$, occurring mainly from October to April. Our observations in Gisagara were conducted from November 2013 to May 2015 (58 weekly surveys) (Table 1).

The nature reserve of Rumonge ( 600 ha) (southwestern Burundi) is located near Mugara ( $\mathrm{S} 04^{\circ} 02^{\prime} \mathrm{E}$ $\left.29^{\circ} 31^{\prime}\right)$ in the Afromontane archipelago-like regional

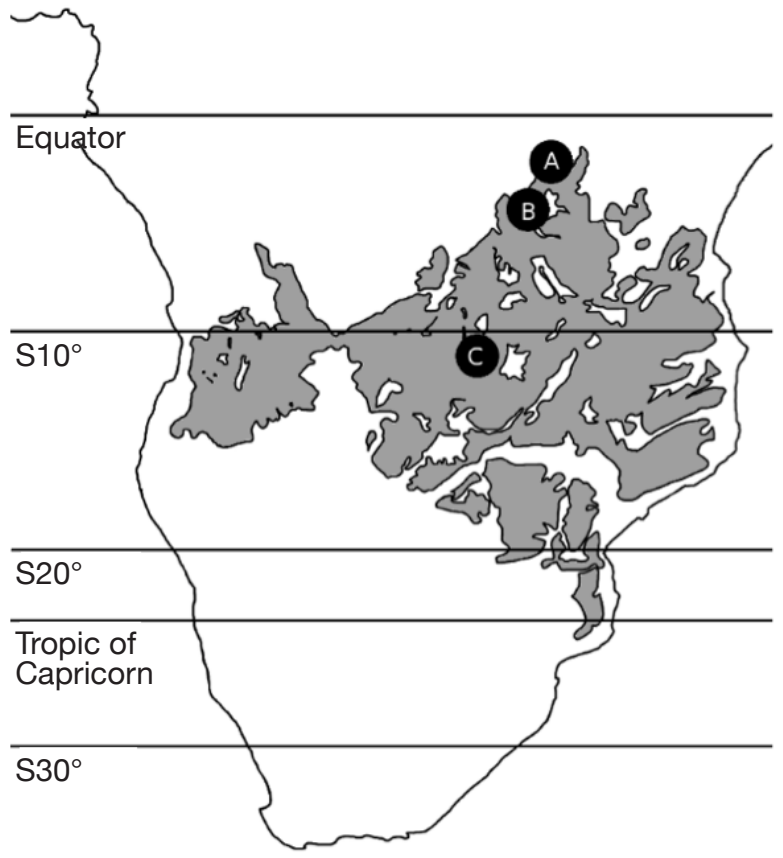

Figure 1. Location of study sites - Localisation des sites d'étude.

A: protected landscape of Gisagara - paysage protégé de Gisagara; B: nature reserve of Rumonge - réserve naturelle de Rumonge; C: Mikembo sanctuary - sanctuaire Mikembo; in grey - en grisé: miombo woodlands distribution area according to White (1986) - aire de distribution des miombo selon White (1986). 
Table 1. Plot characteristics in the study sites: Mikembo sanctuary (DR Congo), protected landscape of Gisagara (Burundi), nature reserve of Rumonge (Burundi) - Caractéristiques des placeaux dans les sites d'étude : sanctuaire Mikembo (RD Congo), paysage protégé de Gisagara (Burundi), réserve naturelle de Rumonge (Burundi).

\begin{tabular}{|c|c|c|c|c|}
\hline Study site & Dominant tree species & Coordinates & Altitude (m) & Plot \\
\hline \multirow[t]{4}{*}{ Mikembo } & Julbernardia globiflora, Brachystegia spiciformis & $\mathrm{S} 11^{\circ} 28^{\prime}$ E $27^{\circ} 39^{\prime}$ & 1,194 & 3 \\
\hline & Julbernardia paniculata & $\mathrm{S} 11^{\circ} 29^{\prime}$ E $27^{\circ} 40^{\prime}$ & 1,235 & 3 \\
\hline & Marquesia macroura & $\mathrm{S} 11^{\circ} 29^{\prime} \mathrm{E} 27^{\circ} 41^{\prime}$ & 1,202 & 3 \\
\hline & Uapaca kirkiana & $\mathrm{S} 11^{\circ} 29^{\prime}$ E $27^{\circ} 39^{\prime}$ & 1,228 & 3 \\
\hline \multirow[t]{2}{*}{ Gisagara } & Brachystegia microphylla & $\mathrm{S} 03^{\circ} 09^{\prime} \mathrm{E} 30^{\circ} 45^{\prime}$ & 1,490 & 2 \\
\hline & Julbernardia globiflora, Brachystegia longifolia & $\mathrm{S} 03^{\circ} 17^{\prime}$ E $30^{\circ} 51^{\prime}$ & 1,438 & 2 \\
\hline \multirow[t]{2}{*}{ Rumonge } & Brachystegia bussei, Uapaca nitida & $\mathrm{S} 03^{\circ} 54^{\prime} \mathrm{E} 29^{\circ} 28^{\prime}$ & 978 & 4 \\
\hline & Brachystegia utilis & $\mathrm{S} 04^{\circ} 01^{\prime} \mathrm{E} 29^{\circ} 35^{\prime}$ & 919 & 2 \\
\hline
\end{tabular}

center of endemism (White, 1986) (Figure 1). The mean annual temperature is $23{ }^{\circ} \mathrm{C}$, and the average annual precipitation is $1,050 \mathrm{~mm}$, occurring mainly from October to April. Our observations in Rumonge were conducted from November 2013 to May 2015 (58 weekly surveys) (Table 1).

\subsection{Diversity inventory and productivity assessment}

In the three study sites, we selected a number of miombo forest types, each characterized by dominant tree species. Two to four plots $(30 \mathrm{~m} \times 30 \mathrm{~m})$ were installed in each of them, making sure they were similar, homogenous, no more than $30 \mathrm{~m}$ apart and at least $10 \mathrm{~m}$ away from the base of very large termite hills. The latter choice is to avoid any bias and heterogeneity caused by the soil characteristics on and around large termite mounds.

Mushroom picking in the plots by local people was stopped during the entire survey period. In the Burundi plots this was implemented with the help of official rangers and strengthened with the support of local chiefs. The plots at Mikembo (Upper-Katanga) are situated within a huge fenced estate. Local people were informed and had no access to the plots.

Due to the relatively short life span of basidiomes (less than 2-3 days), their specific phenology (appearance in time) and reaction to rainfall, inventorying diversity and productivity of mushrooms requires frequent and intensive recording over several years. Data were collected weekly during the entire rainy seasons of 2-3 consecutive years. Each plot was systematically and carefully screened by walking parallel bands of maximum $1 \mathrm{~m}$ wide. All edible basidiomes were picked, identified and sorted per species. Fresh biomass (FB) produced per species per plot was weighed in situ using an electronic scale (Soehnl, precision 0.1 g). The total yields of FB obtained per plot $\left(900 \mathrm{~m}^{2}\right)$ were multiplied by 11.1 to obtain values per hectare. Mean fresh biomass productivity and standard deviations were calculated per study site and expressed in $\mathrm{kg} \cdot \mathrm{ha}^{-1}$. year ${ }^{-1}$.

Reference specimens were collected for each species, then dried with a mushroom field dryer (De Kesel, 2001). They are kept at the mycological herbarium of Meise Botanic Garden (BR) in Belgium.

\section{RESULTS}

\subsection{Diversity of edible mushrooms}

Among the 77 edible fungal species present in our plots, most of them (59 spp.) are ECM with many representativesinCantharellus(15spp.),Lactarius (incl. Lactifluus) (14 spp.), Russula (10 spp.), and Amanita (8 spp.) (Table 2). The scarcity of saprotrophic fungi (15 spp.) compared to dense or montane tropical forests (Degreef et al., 2016; Milenge Kamalebo et al., 2018), is explained by frequent bushfires that systematically eliminate suitable substrates for saprotrophs (leaf litter and rotting trunks) from the miombo woodlands. It is worth mentioning that although our methodology excluded high termite mounds, three representatives of Termitomyces growing from hypogeous nests were nevertheless collected in our plots in Mikembo.

Fungal diversity is much higher in Zambezian miombo woodlands of DR Congo than in any miombo of Burundi. Whereas species compositions within duplicate plots vary very little from year to year, they do vary a lot between plots from different miombo types. In general, woodlands dominated by Uapaca kirkiana (DR Congo) or Uapaca nitida (Burundi) are less diverse than miombo woodlands with an often rich mixture of Caesalpinioideae. Highest diversity of edible taxa was recorded under Julbernardia paniculata (44 spp.) in Mikembo, while the lowest was seen under 
Fungal productivity in miombo woodlands

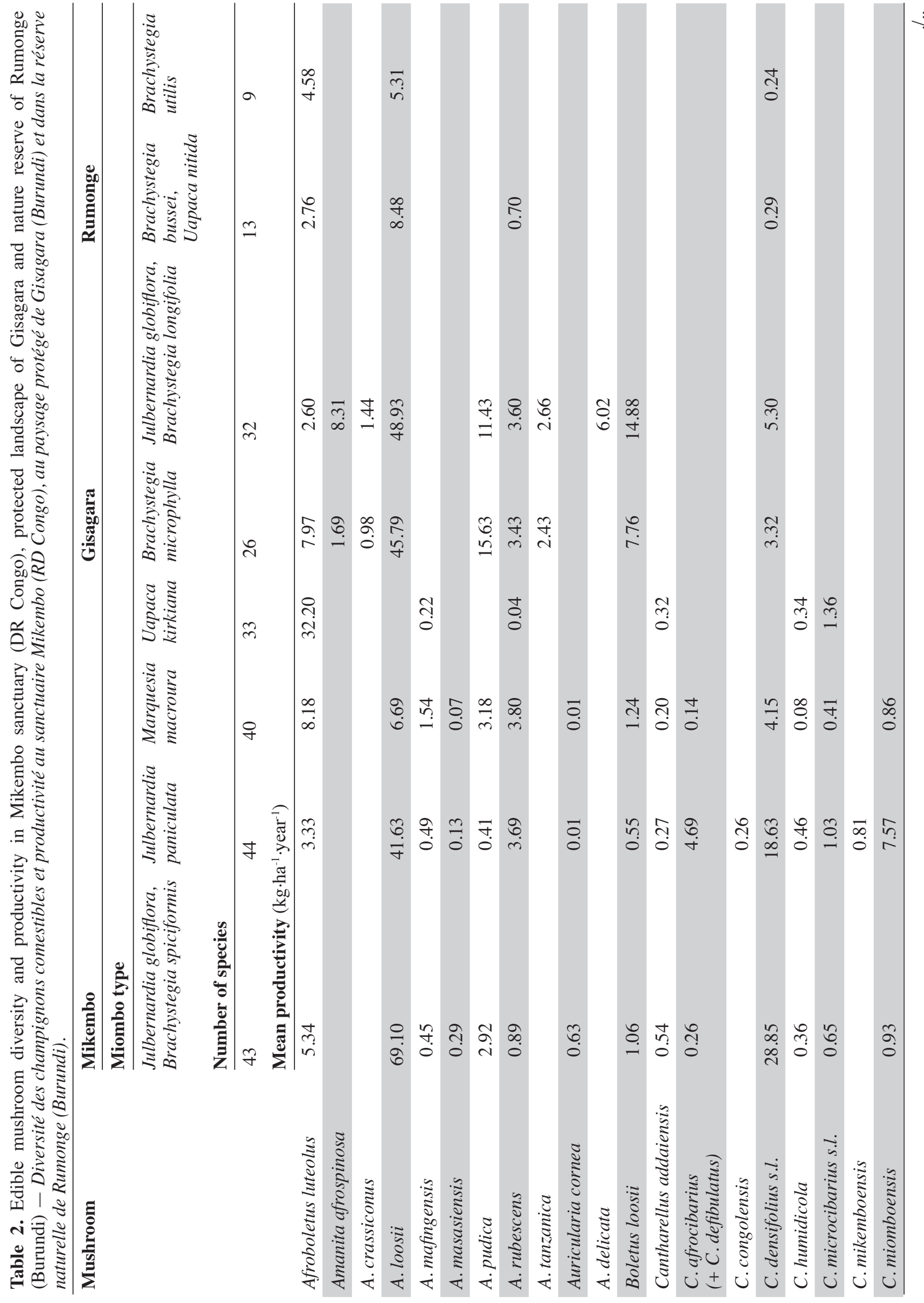




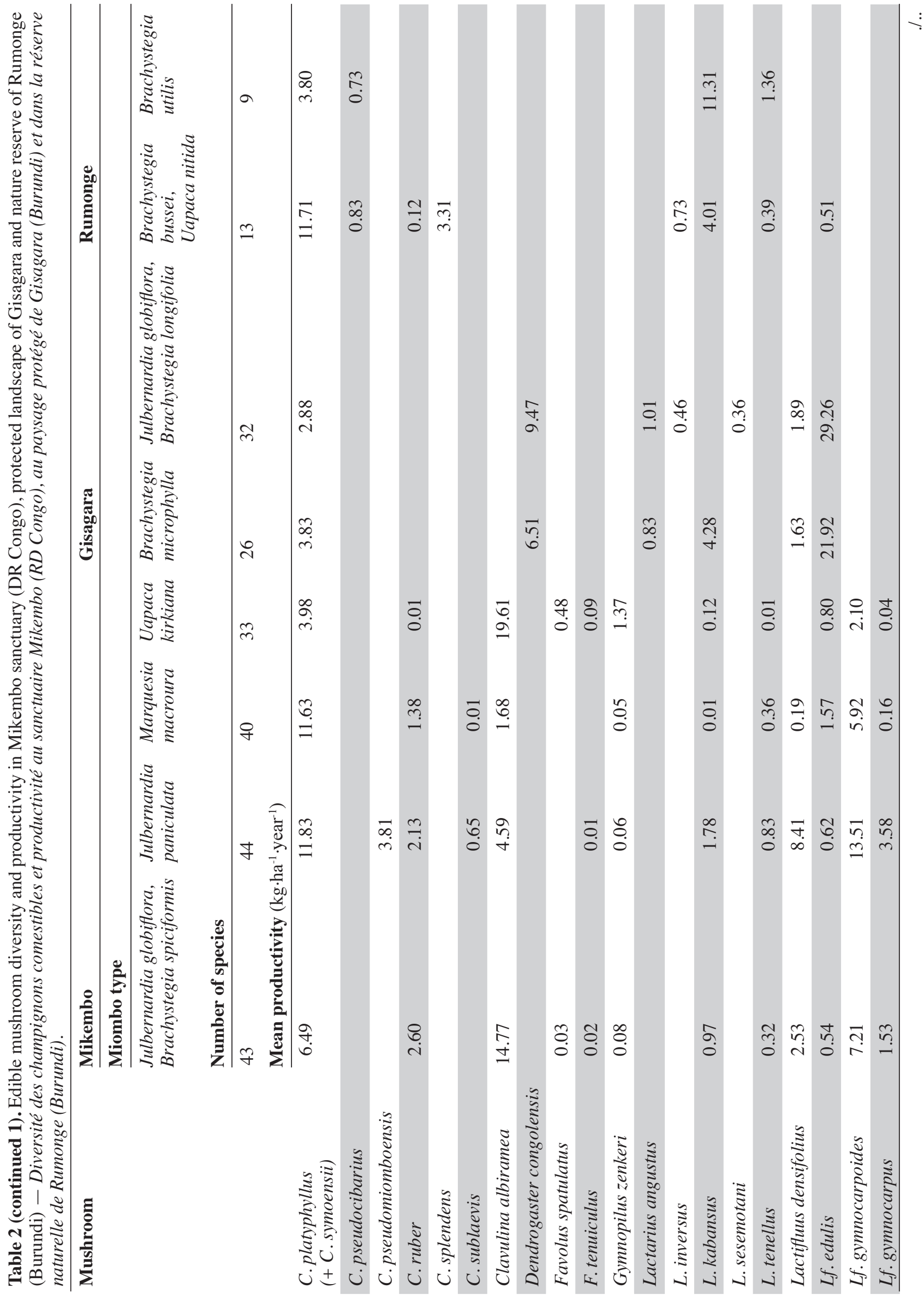


Fungal productivity in miombo woodlands

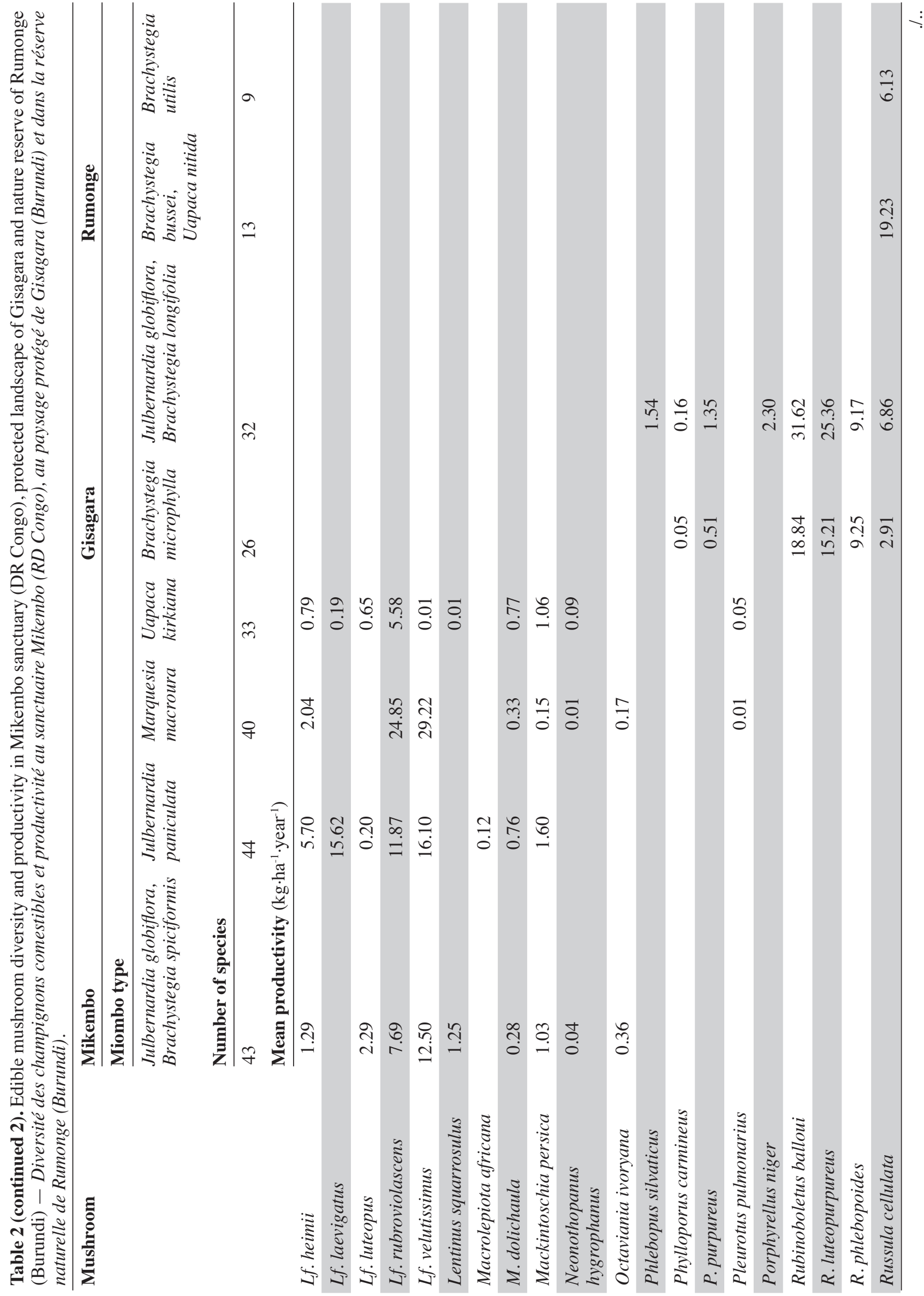




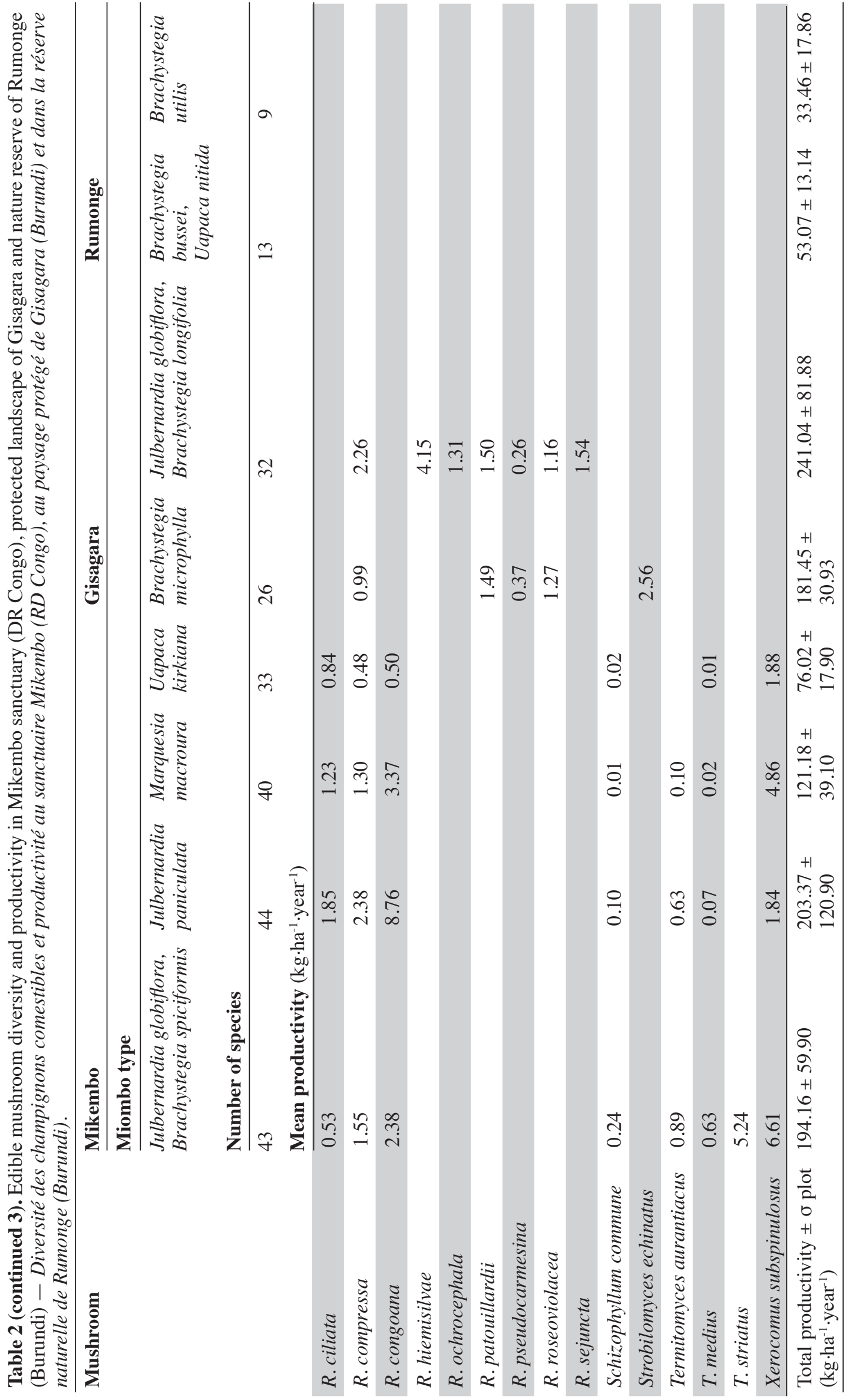


Brachystegia utilis in Rumonge (9 spp.). Except some rare boletes, chanterelles or milkcaps, few of the ECM seem restricted to a single tree species or a specific type of miombo. Only Afroboletus luteolus and Cantharellus platyphyllus (incl. C. symoensii) seem to have a wide ecological amplitude, i.e. occurring in all of the inventoried ecosystems. Even if some species are clearly limited to an ecoregion (e.g. most Lactifluus spp. in the Zambezian region, many Russula spp. in Eastern Africa), most of these edible ECM taxa seem common, i.e. probably associating with various miombo trees, hence present throughout the entire miombo woodland region.

\subsection{Natural productivity}

In contrast to species composition, i.e. hardly fluctuating from year to year, productivity does show important fluctuations within and also between ecosystems. Yearly fluctuations and shifts in FB production within plots are typically explained by changes in rainfall or passage of fire. Since we are interested in mean FB productions per year, it is beyond the scope of this contribution to present detailed information on the impact of rainfall on the specific phenology of species. For the Mikembo plots these data are presented and explained in De Kesel et al. (2017).

According to the miombo type, the mean annual productivity of edible mushrooms varies from $33.46 \pm$ 17.86 to $241.04 \pm 81.88 \mathrm{~kg} \mathrm{FB} \cdot \mathrm{ha}^{-1} \cdot$.ear $^{-1}$. The lowest value was recorded under Brachystegia utilis in Rumonge $\left(33.46 \pm 17.86 \mathrm{~kg} \cdot \mathrm{ha}^{-1} \cdot \mathrm{year}^{-1}\right)$, then more generally in plots containing Uapaca spp. (53.07 \pm $13.14 \mathrm{~kg} \cdot \mathrm{ha}^{-1} \cdot$ year $^{-1}$ in Rumonge and $76.02 \pm 17.9 \mathrm{~kg}$. $\mathrm{ha}^{-1} \cdot$ year $^{-1}$ in Mikembo). The highest biomasses were registered in the three plots hosting Julbernardia globiflora $\left(241.04 \pm 81.88 \mathrm{~kg} \cdot \mathrm{ha}^{-1} \cdot \mathrm{year}^{-1}\right.$ in Gisagara and $194.16 \pm 59.9 \mathrm{~kg} \cdot \mathrm{ha}^{-1} \cdot \mathrm{year}^{-1}$ in Mikembo) or J. paniculata $\left(203.37 \pm 120.9 \mathrm{~kg} \cdot \mathrm{ha}^{-1} \cdot \mathrm{year}^{-1}\right.$ in Mikembo) (Table 2).

The most productive species in all these three sites is Amanita loosii which peaks at $48.93 \mathrm{~kg}$. $\mathrm{ha}^{-1} \cdot$ year $^{-1}$ in Gisagara and $69.10 \mathrm{~kg} \cdot \mathrm{ha}^{-1} \cdot$ year $^{-1}$ in Mikembo, and contributes between 20 to $35 \%$ to the total fresh biomass. The abundance of some boletes like Rubinoboletus balloui, $R$. luteopurpureus and $R$. phlebopoides and their high production in Gisagara woodland (27\% of total fresh biomass) are also worth mentioning. The chanterelles, particularly Cantharellus densifolius s.l. and C. platyphyllus (incl. C. symoensii), profusely fruit throughout the miombo woodlands. Although they represent only $3.5 \%$ production in Gisagara $\left(8.28 \mathrm{~kg} \cdot \mathrm{ha}^{-1} \cdot \mathrm{year}^{-1}\right)$, these miombo flagship species reach 20 to $25 \%$ of the total FB (40.68 to $\left.52.14 \mathrm{~kg} \cdot \mathrm{ha}^{-1} \cdot \mathrm{year}^{-1}\right)$ in Mikembo.
Although host trees can be present, the productivity of some milkcaps is apparently affected by other, unidentified, factors (rainfall, root competition, etc.). So, the productivity of Lactifluus edulis under Julbernardia globiflora is barely $0.54 \mathrm{~kg} \cdot \mathrm{ha}^{-1} \cdot \mathrm{year}^{-1}$ in Mikembo while it reaches $29.26 \mathrm{~kg} \cdot \mathrm{ha}^{-1} \cdot \mathrm{year}^{-1}$ in Gisagara. Milkcaps are particularly diverse and productive in the Zambezian miombo (e.g. with a cumulated productivity of up to $78.22 \mathrm{~kg} \cdot \mathrm{ha}^{-1}$. year $^{-1}$, i.e. $38 \%$ of the total FB under Julbernardia paniculata).

\subsection{Valuable ecosystem services}

The most productive fungal species are also the most selected by the mushroom pickers and consequently the most marketed and consumed in the region. The fleshy Amanita loosii is particularly popular. The 15 species of Cantharellus found in our plots are appreciated by the local populations, with a special mention for C. densifolius and C. platyphyllus (incl. C. symoensii) extensively traded in the studied areas. A wide variety of milkcaps is consumed, particularly Lactifluus edulis which is considered a delicacy in Burundi. Some fleshy boletes belonging to Rubinoboletus spp. are eaten along the Burundi-Tanzanian border while they are generally discarded in most African countries. It is noteworthy that, due to their taste and texture, many Termitomyces species are also a favorite dish but were omitted in this study for methodological reasons.

The impact of mycophagy in the study region remains difficult to evaluate. Up to now very few studies analyzed the nutritional value of African mushrooms and quantified their daily consumption (Parent \& Thoen, 1977; Parent \& Thoen, 1979; Degreef et al., 1997). Calorie-wise edible fungi only play a limited role, but they provide local populations with a set of minerals, vitamins and essential aminoacids, often when classical sources of these substances are depleted or lacking. In most cases the rural poor consider wild edible mushrooms as a valuable and affordable substitute for meat.

Rather than consuming themselves the mushrooms collected in the miombo, most villagers sell them along the roads and in the local markets. The mushroom trade has an important socio-economic impact, generating a significant monthly income of 70 US\$/household, i.e. 400 US\$ annually (De Kesel et al., 2017). Surveys conducted near the study sites reveal that mean market prices of edible mushrooms (more precisely chanterelles, the most abundant traded species) range between 0.30 and $0.83 \mathrm{US} \$ \cdot \mathrm{kg}^{-1}$ in rural areas of Gisagara and Rumonge, and 1.70 US\$ near Mikembo. The prices soar in towns to reach 2.80-4.42 US\$. $\mathrm{kg}^{-1}$ in Lubumbashi (DR Congo) and Bujumbura (Burundi) respectively. 


\section{DISCUSSION}

The amount of annual fresh biomass obtained from edible ectomycorrhizal fungi shows the magnitude of this ecosystem service. Women are the main actors and beneficiaries of the mushroom sector in the region and it is well known that income generated by women is particularly important in terms of development. Although mushroom picking is an ancestral and still relatively widespread activity, the income and advantages it generates are not only underestimated but also threatened. It is indeed the very survival of this fungal resource that is currently questioned.

This ecosystem service is not jeopardized by intensive picking of basidiomes, as this type of extraction does not affect fungal diversity nor future basidiome production (Arnolds, 1995; Egli et al., 2006). African miombo woodlands are also not really threatened by logging because a very low proportion of its timber species are commercially valuable (Campbell, 1996). The main threats to sustainable mushroom production is the annihilation of mycelia by large scale felling of the host trees for charcoaling and slash-and-burn cultivation. Especially host trees in the Caesalpinioideae, i.e. Brachystegia spp. and Julbernardia spp., are targeted for this purpose (Chiteculo \& Surovy, 2018).

This clear cutting, which destroys most, or all of the mature miombo, is the most common exploitation type to get new farmlands. Since various perturbations tend to persist after clear felling, regeneration into woodland hardly ever takes place from fallow, instead a shift to a shrubland thicket may occur (Stromgaard, 1986; Jew et al., 2016). This conversion of woodland into agricultural plots is a particularly acute threat in densely populated regions such as Burundi and the province of Upper-Katanga. In the absence of affordable alternative energy sources, there is an increasing demand for charcoal, leading to overexploitation and large-scale loss of miombo woodland and the irrecoverable loss of the ECM.

\section{CONCLUSIONS}

The potential of non-wood forest products from the miombo woodlands, as well as their socio-economic importance (income and food security), entirely depends on good sustainable management (Dewees et al., 2010). Our findings stress the potential and the importance of the fungal component for the local populations in the area.

Felling ECM trees and collecting ECM mushrooms combines ecosystem services that are a priori incompatible. While the demand for charcoal is constantly increasing in the region, agroforestry systems should be promoting an adapted miombo management strategy instead of clear cutting practices. Considering that the minimum allowable cut diameter is reached from 15 to 60 years (depending on the tree species), mean miombo regeneration time is estimated at 20-30 years (Kanungwe Kalaba et al., 2013). Several systems of sustainable fuelwood extraction exist and have been successfully applied in miombo woodlands (Gumbo et al., 2018) but most of them did not take the sustainability of NWFPs, and particularly the fungus component, into account.

Further research is necessary, but it is suggested that for sustaining ecosystem services delivered by wild edible ectomycorrhizal fungi, the mycelia should remain alive at all times. On soils with forests dominated by host trees from the genera Julbernardia, Brachystegia, Isoberlinia, Uapaca and Marquesia, this can only be obtained by abandoning the practice of clear-felling and possibly also frequent and excessive coppicing. A sustainable land management strategy could rest on the fact that after partial extraction (cutting or coppicing), the majority of miombo trees actually have the capacity to produce shoots from their intact base and root system. Via a rotational management system, where less than the annual regrowth is extracted from a fraction of the trees, ECM fungi will still continue to produce as well. On a sufficiently large scale, such a practice will first guarantee continuity of the ECM mycelia, a better biodiversity conservation, a sustained mushroom yield, but also a reliable/steady charcoal supply. There is little doubt that any type of miombo would be suited for this practice. More research is needed to monitor for example the annual wood regrowths and how the specific communities of wild edible ECM fungi will react to regular coppicing of host trees.

\section{Acknowledgements}

We dedicate this paper to our late colleague Benoît Nzigidahera. As Head of the Biodiversity Research Department at the Burundian Office for Environmental Protection (OBPE), he substantially contributed to the study and valorization of the NWFPs in his country. The authors are grateful to Biodiversité au Katanga (BAK asbl) and to the Mikembo sanctuary for their logistical and financial support to the field work carried out in Haut-Katanga (DR Congo). We also thank C. Gerstmans for preparing the figure.

\section{Author contributions}

Conceptualization and research methodology, J.D. and A.D.K.; data curation, J.D., B.K, E.N. and A.D.K.; writingoriginal draft preparation, J.D.; writing-review and editing, A.D.K. 


\section{Bibliography}

Alday J.G. et al., 2017. Record breaking mushroom yields in Spain. Fungal Ecol., 26, 144-146, doi.org/10.1016/j. funeco.2017.01.004

Arnolds E., 1995. Conservation and management of natural populations of edible fungi. Can.J. Bot., 73(1), 987-998, doi.org/10.1139/b95-349

Boa E., 2004. Wild edible fungi. A global overview of their use and importance to people. Non-wood forest products 17. Roma: FAO, doi.org/10.1663/00130001(2006)60[99:wefago]2.0.co;2

Bonet J.A. et al., 2010. Modelling the production and species richness of wild mushrooms in pine forests of Central Pyrenees in north-eastern Spain. Can. J. For. Res., 40, 347-356, doi.org/10.1139/x09-198

Bonet J.A., Gonzalez-Olabarria J.R. \& Martínez De Aragón J., 2014. Mushroom production as an alternative for rural development in a forested mountainous area. J. Mountain Sci., 11, 535-543, DOI: 0.1007/s11629-013-2877-0

Campbell B., 1996. The miombo in transition: woodlands and welfare in Africa. Bogor, Indonesia: CIFOR, doi. org/10.17528/cifor/000465

Chiteculo V. \& Surovy P., 2018. Dynamic patterns of trees species in miombo forest and management perspectives for sustainable production-case study in Huambo Province, Angola. Forests, 9, 321, doi.org/10.3390/ f9060321

Collado E. et al., 2018. Linking fungal dynamics, tree growth and forest management in a Mediterranean pine ecosystem. For. Ecol. Manage., 422, 223-232, doi. org/10.1016/j.foreco.2018.04.025

Dahl F.A., Galteland T. \& Gjelsvik R., 2008. Statistical modelling of wildwood mushroom abundance. Scand. J. For. Res., 23, 224-249, doi. org/10.1080/02827580802036184

Degreef J., Malaisse F., Rammeloo J. \& Baudart E., 1997. Edible mushrooms of the Zambezian woodland area: a nutritional and ecological approach. Biotechnol. Agron. Soc. Environ, 1, 221-231.

Degreef J. et al., 2016. Wild edible mushrooms, a valuable resource for food security and rural development in Burundi and Rwanda. Biotechnol. Agron. Soc. Environ., 20(4), 1-12.

De Kesel A., 2001. A mushroom dryer for the travelling mycologist. Field Mycol., 2(4), 131-133, doi. org/10.1016/s1468-1641(10)60534-8

De Kesel A., Codjia J.-C. \& Yorou S.N., 2002. Guide des champignons comestibles du Bénin. Cotonou, Bénin : Jardin Botanique National de Belgique \& CECODI.

De Kesel A., Kasongo B. \& Degreef J., 2017. Champignons comestibles du Haut-Katanga (R.D. Congo). Abc Taxa, 17, 1-296.

De Miguel S., Bonet J.A., Pukkala T. \& de Aragón J.M., 2014. Impact of forest management intensity on landscape-level mushroom productivity: a regional model-based scenario analysis. For. Ecol. Manage., 330, 218-227, doi.org/10.1016/j.foreco.2014.07.014

Dewees P.A. et al., 2010. Managing the miombo woodlands of southern Africa: policies, incentives and options for the rural poor. J. Nat. Resour. Policy Res., 2, 57-73, doi. org/10.1080/19390450903350846

Egli S. et al., 2006. Mushroom picking does not impair future harvests - results of a long-term study in Switzerland. Biol. Conserv., 129, 271-276, doi.org/10.1016/j. biocon.2005.10.042

Egli S. et al., 2010. Is forest mushroom productivity driven by tree growth? Results from a thinning experiment. Annals For. Sci., 67, 509, doi.org/10.1051/forest/2010011

Gumbo D.J. et al., 2018. Sustainable management of Miombo woodlands - Food security, nutrition and wood energy. Roma: FAO.

Hernández-Rodríguez M. et al., 2015. Climate-sensitive models for mushroom yields and diversity in Cistus ladanifer scrublands. Agric. For. Meteorol., 213, 173182, doi.org/10.1016/j.agrformet.2015.07.001

Herrero C. et al., 2019. Predicting mushroom productivity from long-term field-data series in Mediterranean Pinus pinaster Ait. forests in the context of climate change. Forests, 10(3), 206, doi.org/10.3390/f10030206

Jew E.K.K. et al., 2016. Miombo woodland under threat: consequences for tree diversity and carbon storage. For. Ecol. Manage., 361(1), 144-153, doi.org/10.1016/j. foreco.2015.11.011

Kanungwe Kalaba F., Quinn C.H., Dougill A.J. \& Vinya R., 2013. Floristic composition, species diversity and carbon storage in charcoal and agriculture fallows and management implications in miombo woodlands of Zambia. For. Ecol. Manage., 304, 99-109, doi. org/10.1016/j.foreco.2013.04.024

Martínez-Peña F. et al., 2012. Yield models for ectomycorrhizal mushrooms in Pinus sylvestris forests with special focus on Boletus edulis and Lactarius group deliciosus. For. Ecol. Manage., 282, 63-69, doi. org/10.1016/j.foreco.2012.06.034

Milenge Kamalebo H. et al., 2018. Uses and importance of wild fungi: traditional knowledge from the Tshopo province in the Democratic Republic of the Congo. J. Ethnobiol. Ethnomed., 14(1), 13, doi.org/10.1186/ s13002-017-0203-6

Parent G. \& Thoen D., 1977. Food value of edible mushrooms from Upper Shaba region. Econ. Bot., 31, 436-445, doi. org/10.1007/bf02912557

Parent G. \& Thoen D., 1979. Considérations sur la teneur en protéines et en acides gras de quelques espèces de champignons comestibles du Shaba (Zaïre). Mushroom Sci., 10, 689-694.

Ribeiro N. et al., 2013. Monitoring vegetation dynamics and carbon stock density in miombo woodlands. Carbon Balance Manage., 8(1), 11, doi.org/10.1186/1750-06808-11 
Stromgaard P., 1986. Early secondary succession on abandoned shifting cultivator's plots in the miombo of south central Africa. Biotropica, 18, 97-106, doi. org/10.2307/2388751

Tahvanainen V., Miina J., Kurttila M. \& Salo K., 2016. Modelling the yields of marketed mushrooms in Picea abies stands in eastern Finland. For. Ecol. Manage., 362, 79-88, doi.org/10.1016/j.foreco.2015.11.040

Tomao A., Bonet J.A., de Aragón J.M. \& de Miguel S., 2017. Is silviculture able to enhance wild forest mushroom resources? Current knowledge and future perspectives. For. Ecol. Manage., 402, 102-114, doi.org/10.1016/j. foreco.2017.07.039
White F., 1986. La végétation de l'Afrique.Paris : ORSTOMUNESCO.

Yorou S.N., De Kesel A., Sinsin B. \& Codjia J.T.C., 2002. Diversité et productivité des champignons comestibles de la forêt classée de Wari Maro (Bénin). In : Robbrecht E., Degreef J. \& Friis I. Plant systematics and phytogeography for the understanding of African biodiversity. Proceedings of the $16^{\text {th }}$ AETFAT Congress, August 28-September 2, 2000, National Botanic Garden, Meise, Belgium. Meise, Belgique : National Botanic Garden, 613-625, doi.org/10.2307/3668706

(33 ref.) 